\title{
Covid-19: All essential workers in England can now be tested
}

\section{Gareth lacobucci}

The BMJ

All key workers in England and members of their households who are showing symptoms of covid-19 will now be able to get tested for the virus, the government has promised. This widening of access, enabled by an increase in capacity, comes as the government is under pressure to meet its target to carry out 100 000 tests a day by the end of April.

From Friday 24 April a new online system is available for employees in essential roles to book a test for themselves or for members of their household who have symptoms of covid-19. Employers can also register and refer any of their staff who are self-isolating at home.

However, as of mid-morning on Friday the site was struggling to meet demand, with messages displaying "applications closed." The Department of Health and Social Care commented, "There has been significant demand for booking tests today. We apologise for any inconvenience. We are continuing to rapidly increase availability. More tests will be available tomorrow."

As well as health and social care workers, the new system is open to other key workers such as teachers, supermarket staff, and delivery drivers. England's health and social care secretary, Matt Hancock, said that it would enable more people to return to work if they and household members tested negative for the virus.

Asked on BBC Radio 4's Today programme whether he expected to meet his target of carrying out 100000 tests a day by the end of next week, ${ }^{1}$ Hancock said, "I do, but nothing is guaranteed in life." He added, "The reason the increase was pretty slow at the start of the month is because we've been building these systems to automate the testing and the labs. We are ahead of our internal plan for where we expected the amount of capacity to be.'

\section{Booking system}

The new booking system allows essential workers to enter their details online at www.gov.uk. They will then receive a text or email the same day, inviting them to book an appointment at one of 30 drive-through testing sites around the country or to receive a home testing kit.

The government is also rolling out other testing methods to improve access for people who do not live close to a testing centre, including new mobile testing units for care homes, police stations, prisons, and other sites; a delivery service for home testing kits, designed with Royal Mail, Amazon, and others, which will be available initially on a limited basis from 24 April; and testing kits sent directly to care homes around England to enable testing of symptomatic residents.

Hancock said that the large increase in capacity was being aided by three large "Lighthouse Laboratories" located in Milton Keynes, Glasgow, and Alderley Park in Cheshire. He told Today that the government now had capacity for 51000 testing capacity and was on track to hit 100000 next week.

However, when it was put to him that capacity was not the same as carrying out test, he said, “There haven't been as many people coming forward as we expected. Access to getting the tests is important-I appreciate especially in some rural areas, and where people don't have a car, [so] we are rolling out home testing."

Ravi Mahajan, president of the Royal College of Anaesthetists, commented, "I am very pleased with the government's actions, and I strongly urge all anaesthetists and intensive care staff across the NHS to work with their employers to ensure that, if they or their family members show symptoms of the virus, they make use of the government's facilities to be tested for covid-19."

1 BBC. Today programme. 24 Apr 2020. https://www.bbc.co.uk/sounds/play/m000hhsn. (Available for 29 days.)

Published by the BMJ Publishing Group Limited. For permission to use (where not already granted under a licence) please go to http://group.bmj.com/group/rights-licensing/ permissions 